\title{
IM HWA, HYBRIDITY, AND THE ANTI-COLONIAL POLITICS OF MODERN KOREAN LITERATURE
}

\author{
Jinhyoung Lee \\ Konkuk University \\ gespenst@hanmail.net
}

\begin{abstract}
This paper deals with the hybridity of modern Korean literature as it tries to explain its anticolonial politics by focusing on the exposition of Joseon literary history and the discourse of the "serious novel" in the late colonial era by Im Hwa, who is considered as one of the foremost critics of modern Korean literature. Im Hwa characterized modern Joseon literature as the result of the hybridization of pre-modern Joseon literature and modern Western literature, thereby devaluing the perceived influence of Japanese literature on modern Joseon literature. This idea was premised on his assumption that the tradition of modern Joseon literature focused on the pursuit of "immaculate individuality." As such, he imagined the "serious novel" as consistent with the form of the Western novel of the $19^{\text {th }}$ century and as a realization of "immaculate individuality." However, due to the political and ideological context of the late colonial era, the apparent modern trait of the "serious novel" was deemed to have broken loose from the ideology embodied in the notion of "East Asia" or the "New Order." As a result, the "serious novel" was believed to have resisted the formal realization of such ideology in what was at that time considered "national literature." In line with Im Hwa's argument, the ideology of "national literature" (in contrast to "immaculate individuality" which was marked by modernity), represented pre-modernity, and hence embodied ideas like collectivity and totalitarianism. Modern Joseon literature, in fact, might be viewed as the result of colonization, having developed as it did under the influence of Japanese literature. Nonetheless, Im Hwa's argument posited the possibility of a combined inscription of literary form and anti-colonial politics in the hybrid formation of modern Joseon literature as shaped by Western modernity.
\end{abstract}

\section{Keywords}

anti-coloniality, hybridity, Im Hwa, immaculate individuality, modernity, "national literature," pre-modernity, "serious novel"

This paper was supported by the KU Research Professor Program of Konkuk University 


\begin{abstract}
About the Author
Jinhyoung Lee is Assistant Professor at the Center for Asia \& Diaspora, Konkuk University. He earned his PhD from Yonsei University and completed a Postdoctoral fellowship at Seoul National University. In addition to his book, Theories of Novel of the Colonial Korea in Late 1930's (2013), he has co-authored other books including After Hybridity (2017), Criticism of Korean Multiculturalism (2016), Topology of Diaspora (2016), Gu Jung-Seo, Walk with His Literature (2015), and Modern Society and Critical Writing (2013). He also co-translated Linda Hutcheon's Theory of Adaptation into Korean (2017) as well as Bakhtin's Prosaics by Gary Saul Morson and Caryl Emerson (2006). His interests include theories of the novel, the Korean novel, criticism in the colonial era, diaspora, hybridity, (post)coloniality, and emancipatory politics in the postcolonial era.
\end{abstract}




\section{LITERATURE AND POLITICS IN THE LATE COLONIAL ERA}

This paper deals with the hybridity of modern Korean literature in relation to its anti-colonial politics by examining Im Hwa's exposition of Joseon literary history and his discursive elaboration of the "serious novel" in the late colonial era.

Japanese imperialism continued to expand its territory through a series of battles such as the Manchurian Incident (1931) and Sino-Japanese War (1937), and strengthen its political and ideological control over the Koreans. At the same time, Singanhoe (新幹會) was disbanded, which had led the independence movement since 1928, and the KAPF (Korea Artista Proleta Federatio) was in disarray, which had actively held literary activities since 1926. In this era, Joseon intellectuals were unable to envision a transformation of society in terms of building the nationstate. They were equally unable to discuss the issue openly and seriously in public journals. Instead, what emerged was the discourse of "the century of fact," ${ }^{2}$ which involved a distrust of the historical perspective in the formation of an independent Joseon nation-state (instead of drawing lessons from it) and an acceptance of the colonial condition as an unchangeable fact (instead of changing it). For example, writers such as Park Yunghee and Paik Chul were convinced of the global victory of fascism as a "fact" or a fait accompli. They became dismissive of the vision of an independent nation-state, and defended the historical legitimacy of Japanese imperialism, declaring the end of Western modernity.

But there were the intellectuals who thought otherwise. Some Joseon intellectuals tried to reconstruct the past, present, and future of the colony by tenaciously presuming "Joseon" to be a relatively independent unity, critical of the imperialist discourse which finally resulted in the recognition of the notion of "East Asia" or "New Order." Such a notion that became a substitute for the aspiration of a nationstate resulted in the negation of the idea of independence for Joseon. In short, their problematique was how to understand the present Joseon society and map out its future in the midst of Japanese victories and the far-reaching propagation of the "East Asia" ideology.

This same problematique faced Joseon literature in the late colonial era. In the face of Japanese assimilation policy, it was thought that modern Joseon literature, which had embodied the notion of the Joseon nation, might lose its cultural identity, as represented as a matter of policy by "national literature," and propagated loudly by the spokesmen for Japanese imperialism around the 194.os. According to colonial propaganda, among other things, "national literature" embodied such qualities like the national consciousness as a creative mind, the thematization of the national position as a critical criterion, and the educational function of literature. In this propaganda, additionally, "nation" was identified with Japanese imperialism. For 
example, the educational function was aimed at turning Koreans into becoming Japanese through literature, and establishing Japanese identity among all the people under its Occupation (Choi Jaeseo 48-59). This development engendered the erasure of nationalities and identities of all national literatures, subjecting them to Japanese nationality and identity.

In this situation, therefore, the alternatives for Joseon literature were limited. One option was to accept the ideology of "national literature" explicitly or implicitly, and the other was to dodge it by not making any references to it. On one hand, the former option may be exemplified by the case of Choi Jaeseo, ${ }^{4}$ who accepted the Japanese colonialism as a fait accompli and actively supported the cause of "national literature." On the other hand, the latter option may be exemplified by Im Hwa who was not interested in this literature entirely and strove to research on the history of modern Joseon literature. Im Hwa was conscious of the heterogeneous sources and hybrid formation of modern Joseon literature, and insisted that underlying the dynamics of modernity and pre-modernity in this literature was the power of literary modernity. His response to the cultural control of Japanese imperialism was an apparent indifference to "national literature" and serious research on modern Joseon literature; this may be construed as his way of resisting the far-reaching dissemination of colonialist literature and propagation of colonial ideology in the late colonial era.

\section{THE HYBRID FORMATION OF MODERN JOSEON LITERATURE}

Several years after he published the essay "Preliminaries to a Discourse of the History of New Joseon Literature" in the mid-1930s, Im Hwa narrated the history of modern Joseon literature by writing a series of essays, including "An Introduction to the History of New Literature" (1939), "A History of New Literature" (1939), "A History of New Literature (continued)" (1940), and "An Introduction to the History of New Joseon Literature" (1940-1). These "literary reflections," which examined the future of Joseon literature, sought to launch "the elimination of reactionary ghosts and illusions, the investigation of the development of new literature and its ongoing state, and then the actual contribution to the upcoming great art and literature" (ILACW2 360-1). But the national situation was fragile. On the one hand, Joseon literature seemed to have veered away from its literary modernity; on the other hand, Joseon writers were passive about the current political and ideological conditions, namely, the political oppression of nationalists and socialists, the Japanese assimilation policy, the dispersion of "East Asia" ideology, and so on. Under this pressing national situation, it would have been hard to continue seeking the modernity of Joseon literature. Understandably, this situation presented a 
dilemma to the critics and writers in the late colonial era, a dilemma to which they could not find a solution. In fact, such a dilemma was expressed by Im Hwa himself when he stated that "[f] or a few years now we have often heard articulated in the literary world expressions such as anxiety or confusion which seem to point to a state of literary disorientation" (ILACW 3 195). Confronted with this situation, his response was to call for the restoration of the "tradition" of modern Joseon literature, specifically emphasizing the significance of the example of the "serious novel" at the core of this literature.

When Im Hwa studied the early modern era regarding the practice of "literary reflections" in modern Joseon literature, what he found was not "the originality of Joseon literature." Instead, what he discovered was that at the origin of modern Joseon literature, there had only been Western literature translated into Japanese and then imported from Japan. Based on this discovery, Im Hwa defined modern Joseon literature as "the literature which described the new realities artistically from the perspective of new ideas and written in the Joseon language with the unity of speech and writing; in other words, a Western-style literature in content and form" (ILACW2 15). It was, in short, "the Joseon literature with the content of modern spirits and in the form of modern genres which originated from Western literature" (ILACW 3 647). One thing to take note of in this quoted passage is the expression "Western-style literature," because it seems to underscore his observation regarding the foreign trait of modern Joseon literature, or its tendency to have Western content and use Western forms. Nevertheless, his definition actually has a semanteme which cannot merely be reduced to foreignness or Western-centrism.

Let us look at Im Hwa's explanation about the "new novel" in the early modern genres. Whereas he evaluated the new novel, Silver World (1908) by Lee Injik, as an exceptional work equipped with Western content and form, he characterized the other new novels-which included Lee Injik's other works, as well as his contemporaries' works in the early modern era-simply as mixtures of the Western modern novel, the Japanese novel, and the Joseon pre-modern novel. However, this characterization was not compatible with his definition of modern literature as the literature with Western content and form. In other words, if this characterization is viewed merely on the surface, it might seem to suggest that most of the Joseon novels would not qualify as modern literature. By his definition, even the Joseon novels of the 1930s could not have reached the standard of the Western-style novel, as he stated,

Nevertheless, we must not forget the fact that the orientation toward the serious novel-which had been formed in Joseon-declined, and therefore the completion of the form of novel in its strict sense as a genre remained a challenge. 
Without this completion, we could not expect the formation of the novel in its strict sense in Joseon, however brilliant the portrayal of life and exquisite the description of the psychological development is. (ILACW 3305 )

Accordingly, it seems inappropriate to adopt the expression "Western-style literature" to refer to the apparent similarity between Joseon and Western literary modernity. Rather, the expression highlights a "newness" in modern Joseon literature - that is, new in its content and form in the Western sense, indicating an orientation toward Western literary modernity (Western = the modern spirit, modern literary genre).

Indeed, the expression "Western-style literature" would have been inappropriate because the novels written by Joseon writers were different from "Western-style literature." From Im Hwa's perspective, although Joseon novelists might have had in mind "Western-style literature" for over 30 years, their works were simply mixtures of modern Western literature, modern Japanese literature, and pre-modern Joseon literature. In other words, modern Joseon literature was a hybrid, which had been influenced by Western literature imported from Japan, in particular, during its early days. Therefore, what bears emphasis is not the literal meaning of the expression "Western-style literature" itself, but what underlies it: the hybridity that characterizes modern Joseon literature.

In this regard, Im Hwa devalued the influence of Japanese literature on Joseon literature. While indicating that modern Joseon literature, as "Western-style literature," had a hybrid form, it was considered hybridized at the exclusion of Japanese literature. Specifically, his devaluation of Japanese literature was influenced in his analysis in two ways: one was by establishing the category "early modern in Joseon," and the other was by distinguishing the influence of Japanese literature on Joseon literature. Still, Im Hwa did not deny the influence of Japanese literature entirely; rather, he tried to define the identity of Joseon literature as distinctfrom Japanese literature by characterizing Joseon pre-modern literature and Western modern literature as two "intrinsic" sources and by assigning Japanese literature the role of an "extrinsic" factor in the formation and development of modern Joseon literature.

First, Im Hwa identified the early modern "Transitional Period" and named it as such rather than "Enlightenment Period" or "The Period of the Cultural Revolution." According to his explanation, the terminology "Enlightenment Period," as used in Japanese literary history, implied "old era," suggesting un-enlightenment and highlighting the importance of Western culture. Similarly, he was critical of the terminology, "The Period of the Cultural Revolution," as used in Chinese literary history which was dismissive of the importance of Western culture. He thought, 
in particular, that the former was not appropriate to indicate the Joseon's early modern era in that it overestimated the function of Western culture. Meanwhile, the latter was not adequate in that it underestimated the function of Western culture. Therefore, these two terminologies were considered inadequate to refer to modern Joseon literature. He thought that in the early modern era, Joseon literature kept "the balance of power" of Joseon pre-modern literature and Western modern literature, and that the adequate terminology had to be "Transitional Period" (ILACW2 134-6).

Second, by setting up the literary works by Joseon novelists in the early modern period as exemplary, Im Hwa tried to devalue the perceived influence of Japanese literature on Joseon literature. Despite knowing that modern literary pioneers such as Choi Namsun, Lee Gwangsu, Kim Dongin and the like had studied in Japan and written numerous works based on their experiences studying abroad, he thought that the actual literary works by Joseon writers demonstrated little of the perceived influence of Japanese literature on Joseon literature:

Except for the old proletarian literature and some short stories, what the new Joseon literature had learned from Japanese literature then and thereafter was very little. If so, did Joseon literature learn directly from Western literature? No, it did not. New Joseon literature, however, developed just by transplanting and imitating Western literature...

New Joseon literature had learned from Western literature by learning from Japanese literature. Besides, Japanese literature gave Joseon literature Western literature rather than giving itself to Joseon literature. This process was practiced through the three routes of translation, creation, and criticism. (ILACW 3 654)

This quotation seems to have two meanings. One is that Japanese literature, which was imported into Joseon, was really just a variation of Western literature. The other is that modern Joseon literature was oriented toward Western literature rather than Japanese literature in its spirit and form. With regard to this, Im Hwa insisted that even old proletarian literature and some short stories-which were considered to be the parts of literary modernity then-were among the examples of forms that had not reached literary modernity. In fact, he says, "[t]he new literature, which was even more feudal than individualistic, and the proletarian literature, which was even more collective than individualistic, could not complete the form of novel in its strict sense in Joseon" (ILACW 3 297). This insistence might be controversial, of course. However, the point here is that since he could not deny the influence of Japanese literature on modern Joseon literature, he tried to devalue this influence by making literary modernity the exclusive property of Western literature. 
Moreover, Im Hwa explained that underpinning the history of modern Joseon literature were the dynamics of Joseon pre-modern literature and Western literature. ${ }^{5}$ For example, he regarded Lee Injik's novel Silver World (1908) as the one-and-only modern style of the "new novel," and then considered his later works (alongside the new novels by the other writers, which were published after Silver World) as representative of "a process of abolition of the form of new novel" (ILACW2 346), which meant the process of losing their literary modernity. For him, in Silver World, the modern was superior to the pre-modern in terms of its spirit (overcoming feudal ideas and practices) and form (literary realism). However, in the other works representing the new novel, the pre-modern became superior to the modern. Therefore, he insisted that the direct descendant of Silver World was to be found in the novel, Mujung (無情; 1917) by Lee Gwangsu. In other words, despite the publication of a lot of new novels by Lee Injik and his contemporaries that immediately followed Silver World, these works were deemed pre-modern in their spirits and forms, whereas Lee Gwangsu's Mujung was deemed to have successfully restored the superiority of literary modernity.

Consequently, Im Hwa's exposition of modern Joseon literary history may be viewed as a kind of foreshadowing of his effort to restore the tradition of Joseon literature, which had passed through its hybrid formation and developed under the dynamics of Joseon pre-modernity and Western modernity but now seemed to be in danger of deviating from this development. From this effort, he finally arrived at a recognition of the elements and processes involved in the identity of originality as well as hybridity, tradition, and transplantation when he stated, "when cultural transplantation becomes increasingly enhanced, cultural creation also becomes mature" (ILACW2 657). In keeping with this recognition, he asserted that the form of the "serious novel" is consistent with Western literature, regarding it as a realization of literary modernity.

\section{THE INVENTION OF THE MODERN LITERARY TRADITION: THE "SERIOUS NOVEL"}

In order to deepen the exploration into the modernity of Joseon literature, it is important to keep in mind that modern Joseon literary tradition found meaning in the attempt of elucidation. This is the same modern Joseon literary tradition which Im Hwa reconstructed in the late colonial era. According to Im Hwa, "as a result of liberation from the foreign language which had controlled our literature for so long, our new literature took a leap from the old one in terms of language, form, and content" (ILACW 2 19), It may be inferred from this statement that the three "leaps" consisted of the following. The first one was the linguistic leap. Specifically, whereas, 
in the pre-modern era, Joseon literature had been written by Chinese characters, modern literature was written in Hanguel (Korean script, and thus in the Korean language). The second was the formal leap. Modern Joseon literary genres, such as poetry, novels, plays, and the like, were formed for the most part to be consistent with the modern Western ones. The third was the spiritual leap. That is, modern literature expressed the bourgeois spirit, or "immaculate individuality," freed from the pre-modern ethics based on fidelity and filial piety. In short, modern Joseon literature was defined by the pursuit of linguistic independence, formal modernity, and the bourgeois spirit.

For Im Hwa, the Joseon "serious novel," for all "its insufficiency, the tradition of Joseon novel lay firmly" in it (ILACW3 293). For certain, it was consistent with the Western novel of the 19th century, but it was the realization of literary modernity shaped through the three instances of leaps in Joseon, "the 19th century novel that we were longing for before, that is, what we had called the 'serious novel"' (ILACW 3 328). Im Hwa states:

The classical novel written by Balzac, Zola, Tolstoy, Dickens and the like was structured around the fate of a protagonist and was composed of the seamless continuation of life woven from a character and its circumstance, and expressed the authors' ideas through this structure.

In this sense, it was natural that we regard the novel (including short stories as well as full-length novels) the epic of bourgeois society (ILACW3 291).

The form of "serious novel" was fundamentally characterized by the protagonist's struggle against his circumstances through his attempt to fulfill his desire. Indeed, this narrative was the basic structure of the Western realist novel in the 19th century. Whereas the form of the Joseon pre-modern novel was shaped by the realization of Confucian moralities (loyalty, filial piety) on the basis of "family," the form of the modern novel was constituted by the realization of "immaculate individuality" ("writer's idea") on the basis of "individuality" ("the fate of protagonist"). This is what was referred to by "the epic of Bourgeois society." It may be worth mentioning that in Im Hwa's discussion of the "serious novel," he did not deal with the problem of language, because he thought that the "linguistic turn" in Joseon had been completed during the "Transitional Period." Indeed, in the 1930s, most writers used the Joseon language (Hangeul). As a result, he might have thought that the urgent problems for Joseon writers in this era primarily concerned modern literary form and content.

Meanwhile, Im Hwa's conception of the "serious novel" was conditioned by the awareness of the problem of the contemporary novel, the reflection on modern Joseon novels, and the reading of György Lukács' essay “The Novel as the Epic 
of Bourgeois Society" (1936). ${ }^{6}$ As a matter of fact, Im Hwa started to discuss the "serious novel" earnestly in the mid 1930s, when he introduced Lukács' thesis "the novel as Bourgeois epic" and his argumentation of the Western novel, as well as writing "the preliminaries to the history of Joseon new literature." However, his writing was not an imitation of Lukács' essay. In fact, it did not completely coincide with Lukács' argument. For example, he pointed out that Zora was one of predecessors of "serious novel," while Zora was the writer that Lukács criticized as a naturalist.

Despite their common recognition of the Western novel of the $19^{\text {th }}$ century as a historical ancestor of the modern novel as a literary genre, there was a gap between Im Hwa's "serious novel” and Lukács' "bourgeois epic." This was perhaps because Im Hwa's discourse on the "serious novel" was based on the reading of contemporary literary essays, as well as of Lukács' essay, rather than a detailed research on the Western novel of the $19^{\text {th }}$ century. Apart from a clear evidence of his deep interest in the Joseon novel of the late 1930s, there was no evidence of equally serious research on the Western novel. Therefore, for him, whether or not Zora was the predecessor of "serious novel" was meaningless. His interest was only in the radical innovation of the Joseon novel in the late colonial era; that is to say, in the restoration of literary modernity. So, it can be said that the $19^{\text {th }}$ century novel is the historical and logical example of the modern Joseon novel or literary modernity.

Accordingly, the significance of Im Hwa's narration of Joseon literary history was not in its factual presentation, but rather in its search for a way of realizing literary modernity; that is, of "immaculate individuality" as its spiritual instance. In this view, the significance of Lukács' essay could be found as a theoretical reference for advocating the legitimacy of the "serious novel." This is to say, it advocated the novel as a genre that is illustrative of the realization of "humanist subjectivity." More specifically, in the 1930s, when the imperialist and fascist regimes were expanding their spheres of influence, such concepts as self-activity, action, or practice-the notion of "immaculate individuality" - needed especially to be restored because of the possibilities it provided for resistance to both types of regimes based on humanist reason (Keßler 294).

In the dispute among scholars of literature about the novel in late colonial era, therefore, Im Hwa defended the "serious novel" and insisted on the necessity of its restoration. This was a matter of course because for him the "serious novel" was equal to modern literature and meant the same thing. At the same time, he knew well that it remained a work in progress in the colonial Joseon. In fact, he states: 
Finally, Joseon novels so far are maintaining a form of the serious novel, just as they have not the characteristics of the completed tradition, but only the uncompleted, and then, the one to be completed, as I said earlier, of course (ILACW 3293 ).

Actually, these days writers already seem to have lost their orientation toward the form of novel in its strict sense - in its modern sense - as it is to be completed in Joseon (ILACW3 295).

As shown in the above quotations, Im Hwa insisted that Joseon novelists had to complete the project of developing modern Joseon literature by restoring its tradition of the orientation toward the "serious novel," thus actually realizing "immaculate individuality" as the core of literary modernity in this form.

Consequently, the "serious novel" in particular was a hybrid form shaped by considerations in the reception of the Western novel in the $19^{\text {th }}$ century and the critical understanding of Joseon novels in the late 1930s, just as modern Joseon literature in general was hybrid, oriented toward modern Western literature, and at the same time marked by pre-modern literature. In this regard, the "serious novel" could be called the form of the Joseon novel, not the form of the Western novel in the $19^{\text {th }}$ century. In other words, it was not just a transplantation or imitation of modern Western literature or a representative of it, but a form of indigenization of Western modernity; that is, the form for realizing "immaculate individuality." From this perspective, Im Hwa thought that, just as Joseon novelists endeavored to complete the uncompleted project of modern Joseon literature, the literary tradition of Joseon as a cultural unity could be restored, and the literary disorientation of the late 1930 s could also be overcome, accordingly.

\section{THE POLITICS OF LITERARY FORM}

So far, Im Hwa's explanation about modern Joseon literature seems simple. For him, modern Joseon literature was formed and developed through a dynamic interplay of pre-modern Joseon literature and modern Western literature on the basis of the orientation toward the latter. In his literary history, the bourgeois spirit as "immaculate individuality" was regarded as the most important instance of literary modernity, and the modern tradition of Joseon literature in the "serious novel" was the form for realizing such a spirit. In brief, modern Joseon literature was a hybrid literature oriented toward Western modernity. But, his argumentation reveals other meanings if we put it into its political and ideological context in the late colonial era in which his thought developed. At this point, it may be understood why he had to devalue the perceived influence of Japanese literature on modern 
Joseon literature in his description of its hybrid formation and development. Moreover, it may become clearer why he should insist on the necessity of restoring the "serious novel" in asserting that it was the realization of modern literature. Specifically, for him, such devaluation seemed like a prerequisite for imagining Joseon as a self-reliant cultural unity and narrating its history independently of Japanese imperialist view of history.

In the late colonial era, Japanese intellectuals propagated the superiority of Eastern ethics and the world-historical necessity of the "New Order" based on "morality." In this, the first principle of "morality" was "hakkō ichiu" (八紘一 宇) ${ }^{8}$, which means "all the world under one roof" - that is, "the co-existence and co-prosperity of all nations." The image for this conception of the "New Order" was the model of a feudal society based on the Japanese warrior family. Japanese ideologues asserted that Japanese feudal society, as a community based on "personal confidential relationship," was a system that ensured personal freedom and right, which could be the alternative to the Western nation-state system based on inequality and dominance. But that conception presumed the sovereign-andsubject relationship centered on the Japanese emperor and the co-existence and co-prosperity of all the Asian nations within Japanese imperialism. In this context, Koiso Kuniaki (小磯國昭), who was a proconsul of colonial Joseon, also insisted on "the establishment of a moral Joseon" as an important basis of government rule. As a result, the notion of "New Order," in fact, entailed a relationship of sovereign and subject that was centered on the Japanese emperor, and its conception of the community based on the co-existence and co-prosperity of all the Asian nations could actually be established only through their subjection to Japanese imperialism.

At the same time, Choi Jaeseo, who had published a number of critical essays in this era, actively accepted the Japanese ideology of "East Asia" and sought to realize this ideology through the construction of a "national literature" that was strongly propagated by Japanese ideologues. For Japanese imperialism whose interest was to win a series of wars in the 1930s, establishing a "national literature" was an effective strategy in establishing the cultural unity of Japanese colonies. Most important is how Choi Jaeseo characterized "national literature" as the antithesis of modern Western literature and, at the same time, as a meta-literature that could encompass all the national literatures. Specifically, he described it not as "the extension of modern Western literature" but as "literature implying an ideal of the Japanese nation based on the synthesis of Eastern and Western cultures under the Japanese spirit" (Choi Jaeseo 49). Despite his contention that "national literature" would not arrogate upon itself the distinct cultural identities of such sub-nations as Joseon, Taiwan, and China, his view that Joseon literature as a "national literature" should become a sub-literature of Japanese literature and contribute to the establishment 
of "moral Joseon" based on the "Eastern ethics" presumed the legitimacy of the Japanese imperialist system. ${ }^{9}$

Regarding the issue of "national literature," Im Hwa did not directly contradict the notion itself, perhaps because to express the rejection of "national literature" publicly might have been almost impossible in the late colonial era. However, what seems more important is that "national literature" was apparently not compatible with Joseon literary modernity; that is, "national literature" was deemed a problem to be solved through literary discussions, not a solution to be simply accepted. For example, Choi Jaeseo had insisted that "national literature" went against Western modernity and was dismissive of the orientation toward literary modernity. In other words, "national literature" implied forcing Joseon writers to write in the Japanese language and abandoning modern Western literary genres through, for example, privileging Japanese epic over modern Western literary genres, and highlighting "immaculate individuality" of "Eastern ethics" at the expense of ideas foregrounding individual ethos and practices. He states:

Nowadays, Japanese literature would strengthen its spiritual purity by maintaining its tradition and clarifying the national body, on the one hand, and at the same time broadening its range of influence by containing the other nations and establishing the new world, order, on the other. While the former has the tendency to return to the Japanese emperor, the latter has the tendency to present the hakko ichiu. These two sides should be completed without any contradiction or antagonism. The Japanese spirit will harmonize these two sides, and allow no rupture between them. (Choi Jaeseo 76)

In comparison with Choi Jaeseo's argument for "national literature," Im Hwa characterized modern Joseon literature in this era as being conditioned by the particularity of Joseon society and literature "which had never been bourgeois" (ILACW5 186). As pointed out earlier, he characterized modern Joseon literature as a hybrid form of pre-modern Joseon literature and modern Western literature, thereby devaluing the perceived influence of Japanese literature on Joseon literature. In addition, he argued that modern Joseon literature had developed as a result of the dynamics between Western modernity and Joseon pre-modernity. As such, the tension or conflict was not between "Joseon" and "West," but between pre-modernity and modernity. In his exposition on modern Joseon literary history, what bears emphasis was not the geographical opposition between "Joseon" and "West," but the temporal opposition between pre-modernity and modernity, thus following the process of transcending of pre-modernity by modernity. ${ }^{10}$ Therefore, modern Joseon literature was a hybrid resulting from the conflict between "the West" as represented by modernity" and "pre-modernity," which is oriented toward transcending "pre-modernity" by "West-modernity" 
Accordingly, while "pre-modernity" referred explicitly to the characteristic of pre-modern Joseon literature, it could also be deemed as a reference to Japanese "national literature" in the context of the political and ideological conditions in the late colonial era. For Im Hwa, collectivity or totalitarianism was suggestive of its "pre-modernity" as he states that "without individuality, the interest on totality could not be bourgeois, as a thick layer of residue from semi-feudalism remains cumulative" (ILACW2 444). Moreover, he explains that "the actually modern, humanistic demands could be suggested only after returning to the viewpoint of individuality, leaving the viewpoint of sociality first" (ILACW2 445). In this sense, to be modern or to be bourgeois would be possible by acquiring the viewpoint of individuality. On the other hand, the adherence to totality was likely to fall into semi-feudalism. In this context, indeed, "Japanese literature" or "national literature" which insisted on collectivity and universality would fall under the category of "pre-modernity."

Despite Im Hwa's argumentation, however, all of the new novels and proletarian literature, and above all, the "national literature," were produced by modern authors in the modern era. That is, even the pre-modernity of these forms would be the strategy of the modern writers. As Japanese ideologies were "the result of the modernization that Japanese society had undergone, and the strategy for responding to this result well" (Lee Chulwoo 102), "national literature" was also a literary-critical strategy for achieving and maintaining the unity of the Japanese empire as a kind of modern regime of government. In this regard, it could be said that there were two types of literary modernity in the late colonial era: one was the "serious novel" (which may be said to refer to "Western literature"), and the other was "national literature" (which may be said to refer to "Japanese literature"). At this point, a kind of binary opposition may be set up between the serious novel (modern Joseon literature) and national literature, on one hand, and between modernity (immaculate individuality) and pre-modernity (collectivity or totalitarianism), on the other. As such, the latter could be called "reactionary modernism" (Osborne 167) in that it had its orientation toward the past. Therefore, Im Hwa's demand for the "serious novel" could be considered the postulate for the modernity of Joseon literature as opposed to the pre-modernity of "national literature," namely, a type of literary "reactionism." Thus, the most important feature of his exposition of Joseon literary history was that such oppositions could imply an ultimate identity between his demand for the "serious novel" and his rejection of "national literature."

Im Hwa's insistence on the realization of modernity may be viewed as an explicit opposition to the ideology which arrogated upon itself the transcendence of Western modernity in the name of the Eastern. It may be pointed out that such realization could emasculate not only the Japanese ideology of "East Asia," which presumed the dichotomy of "East/West" and the transcendence of Western modernity based on 
this, but also reject the historical project of pre-modern ethics. If so, what should be transcended was not Western modernity but Japanese modernity as a premodern form of "familism." Actually, the orientation of the latter was only toward the return to the assumed past of Japanese culture, not toward such transcendence. Accordingly, modern Joseon literature had to proceed in a way of transcending "Eastern ethics" by realizing "immaculate individuality." From Im Hwa's perspective, "the formation of immaculate individuality freed from nations or classes remains the task of our society" (ILACW 5 186), and this task could be completed only by modern Joseon literature as a hybrid literature.

\section{HYBRID MODERNITY AND ANTI-COLONIALITY}

The fact that the reactionary modernity of Japanese imperialism was responsible for the impossibility of bringing the modernity of Joseon literature to completion was also hinted at in Im Hwa's argument on the task of Joseon literature in the late colonial era.

From now on, Joseon literature must proceed forward by following Western literature and paying attention to the oppression by Japanese literature. This may be a process that cannot be stopped, and could destabilize the artistic world endlessly. Because art always has to complete its work in its own era (ILACW5 511).

Therefore, for Im Hwa, Joseon literary modernity could be realized only as it tries to reconstruct its own tradition. At the origin of this literature was hybridity, and "no matter what it says, the first mark of the time when modern Joseon literature was born was also its last mark" (ILACW 5 512). That is, the origin of modernity in Joseon literature, its orientation toward the Western form and spirit-as in the example of the "serious novel" and "immaculate individuality" - should ultimately be fully realized in its literary forms in the future. In addition, this literature should take the form that broke loose from the "national literature," of course, which presented itself as an alternative to Western modernity.

To sum up, for Im Hwa, modern Joseon literature was deemed a hybrid form of pre-modern Joseon literature and modern Western literature. At this point, his theoretical and historical elaboration on the "serious novel" could be appreciated as a verification of Robert Young's proposition in his book Colonial Desire: Hybridity in Theory, Culture and Race (1995) that "the hybridity of colonial discourse thus reverses the structures of domination in the colonial situation" (21). In other words, the self-contained regime of colonial power could be fractured in the face of the hybridity of the discourse which had formed and developed in 
the colonial situation. Discursively produced in the intersection of the language of the colonized and the colonizer, literary-critical hybridity produces cracks in the presumed self-containment and purity of the colonial regime by exposing the existence of heterogeneous and contradictory factors within the colonial regime itself, suggesting possibilities for anti-colonial alternatives. In this regard, modern Joseon literature might be seen as a result of colonization in that it grew by means of Japanese literature. However, Im Hwa's argument definitely demonstrated the possibility of associating the literary hybrid and anti-colonial politics, arguing for the hybrid formation and development of modern Joseon literature with an orientation toward Western modernity. Therefore, with Im Hwa's literary history, yet another door was opened toward anti-colonial politics by understanding the cracks that were formed somewhere in the assumed monolithic discourse of the oppressive Japanese colonial regime in Korea. 


\section{Notes}

All quotations in this article are my translations.

1. Im Hwa (1908-1953), whose real name as Im Insik, wrote over 80 of poems and over 200 critical essays. His works constitute the basic readings in the study of the history of modern Korean poetry and modern Korean criticism. Specifically, his study of modern Joseon literary history is a pioneering attempt at writing aspects of modern Korean literary history which have become must-read in Korean literary scholarship. He was the chair of KAPF (Korea Artista Proleta Federatio, 1925-1935), a leading artist group of the communist movement during the colonial era, which, after the liberation from Japanese colonialism, struggled for the creation of an independent communist nation-state in South Korea. Just after the Korean War, however, when he moved to North Korea, he was shot to death on allegations of being an American spy by the North Korean government.

2. "The century of fact" is a term coined by Paul Valéry to indicate the characteristics of Western culture in the $20^{\text {th }}$ century. By understanding the world order in the $19^{\text {th }}$ century as a kind of fictional construction and the $20^{\text {th }}$ century as a barbaric era prior to humanistic history and culture, he demanded the necessity of recognition of this century as "the century of fact." Because, for him, the type of understanding in the $19^{\text {th }}$ century based on the notion of "order" or "rule" had been discredited in the face of the facticity of the First World War in the $2 \mathrm{O}^{\text {th }}$ century, exposing its fictiveness, and, accordingly, the loss of its cognitive power, from which Western civilization in $2 \mathrm{O}^{\text {th }}$ century had suffered. Many Joseon intellectuals thought that the thesis of "the century of fact" described the situation of Joseon society in the 1930 s well. For them, this era renders illegitimate the notion of "independent national state" as a historical perspective, and the ideology of "East Asia" which was propagated as the alternative historical perspective by Japanese imperialism.

The thesis of "the century of fact" was imported into Colonial Joseon via the writings of Kawakami Tetstaro (河上徹太郎). The process by which the thesis was imported is described well in Cha Seungki's article (2008). Drawing on his explanation, for Japanese intellects, the break-out of Sino-Japanese War (1937) was the event which demanded the different "New Order" from the existing order. The extension of Japanese territory by a series of battles was followed by the necessity of social and institutional changes, and accordingly most of Japanese intellects tried to accept the era of these changes as "the century of fact." The Joseon intellectuals' understanding of this thesis was premised on his explanation.

3. Japanese intellectuals propagated the discourse of "East Asian New Order" seriously, advocating for a series of wars aimed not at the expansion of Japanese territory, but at the establishment of the "New Order." In particular, the spokesmen of the discourse of "East Asian Cooperation" grounded its validity in the perceived overcoming of antagonisms between the colonized and the empire, and in the 
belief that the formation of a new East Asia could assure the independence and cooperation of all the nations (Kim Heuiju 69-72; Yonetani Masahumi 164-7).

4. Choi Jaeseo (1908-1964) was a professor of English Department of Kyungsung Imperial University (formerly known as Seoul National University), and director of the publishing house Inmunsa. which launched the journal Inmunpyungnon, which in turn specialized in the Humanities. He was a very influential figure during the late colonial era whose impact upon the Joseon literary world owed to the essays that he wrote about current Joseon literary works and Western modernist literary theory. In the late colonial era, about the outbreak of Pacific War, however, he exposed plainly his position as being on the side of Japanese Imperialism, and collaborated actively as a literary spokesman for the colonizers, for example, by insisting that the "national literature" be Japanese.

5. For example, there is also the argument that Im Hwa's devaluation of the perceived influences of Japanese literature on modern Joseon literature is due to his treating it not as an object of imitation or criticism, but as something like a "window" (Chae Hoseok 16-7). In light of Im Hwa's ignorance of Japanese literature, this argument is not irrelevant, but what we must emphasize is the definite exclusion of Japanese literature from modern Joseon literary history. That is to say, Japanese literature was deemed not an object of indifference, but an object of negation.

6. György Lukács' "Novel as Bourgeois Epic" was an essay written for the publication of a literary encyclopedia in the USSR in the early 1930s. This essay was introduced into Japan by Kurozawa Madakuro (態澤復六). He published two books, The Essence of the Novel (Theory of the Novel) (淸和書店, 1936) and The Novel and Short Story (淸和書店, 1937), and the first was a translation of “The Novel as the Epic of Bourgeois Society." This translation had a great impact on Joseon and Japanese literary critics. Illustrative were the discussions which took place amongst Joseon literary men in the late 1930 (Lee Jinhyoung 35-244). Echoes of Lukács' essay can of course be found in many of Im Hwa's writings in the late 1930s.

7. For example, Japanese intellectuals insisted on the significance of a new world order based on "morality" and the necessity of this order. With regards to this, Koyama Iwao (高山岩男) said:

There are profound differences among men as mortal beings. Therefore, morality should control the world full of differences. In this, morality means that the wise and the ignorant 'find their own levels' in this world. This is the reason of the politics of the wise philosopher. True harmony (和) could be completed by realizing this politics that lets the wise and the ignorant do their duties (Nakamura Mitsuo, Nishitani Keiji 274).

8. The term hakkō (八紘), meaning "eight crown cords," is a metaphor for "eight directions," and the term ichiu (一宇), meaning "one roof," is a metaphor for "one center."

9. With regards to this point, Choi Jaeseo states that:

But it is not my intention to claim that Joseon writers must not say anything about "Joseon." Joseon writers have to research the old and the new of Joseon, and seek and write the good, the beautiful, and the sad. As Japanese nations, however, 
they have to do so. We have to reject the works or discourses that bring about the illusion that the Joseon people have only Joseon nationality and ignore Japanese nationality (Choi Jaeseo 99).

10. It may not be accurate to categorize Im Hwa simply as a "modernist," who was enthralled by "Western modernity" by setting up the binary opposition between "West" and "East." For example, Im Hwa has been criticized for naturalizing the stagnation of Joseon society and oppressing and rejecting Joseon tradition by regarding Japanese orientalism as a form or variation of Western orientalism." As such, "his writing of new literary history as being conducted under the influence of orientalism could be said as a typical response of a colonial intellect experiencing the invasion of Western modernity" (Kim Oegon 9o). As his argument, it could be assumed that Im Hwa had a certain notion of the identity of "West" and "modernity." But this assumption does not need to imply any essentialist identity of "East" and "pre-modernity." For example, for Im Hwa, Joseon literature, Japanese literature, and Chinese literature were not the same. Rather, in the late colonial era, he emphasized on the difference of these literatures which could not be reduced simply in "East" or "pre-modernity." 


\section{Works Cited}

Chae, Hoseok. "The Mirror of the Post-colonial and Im Hwa." Journal of Korean Studies, vol. 17, 2002, pp. 59-86.

Cha, Seungki. "'The Century of Fact.' Contingency, The Ethics of Collaboration." Journal of Korean Literary History, vol. 38, 2008, pp. 264-304.

Choi, Jaeseo. Joseon Literature in Turning Point. Translated by Roh Sangrae. Youngnam University, 2006.

Im, Hwa. Im Hwa's Literary Art Collective Works 2: Literary History (IWLACW2). Edited by Im Hwa's Literary Art Collective Works Compiling Committee. Somyong, 2009.

--. Im Hwa's Literary Art Collective Works 3: The Logics of Literature (IWLACW3). Edited by Im Hwa's Literary Art Collective Works Compiling Committee. Somyong, 2009.

-.. Im Hwa's Literary Art Collective Works 5: Critical Works 2 (IWLACW5). Edited by Im Hwa's Literary Art Collective Works Compiling Committee. Somyong, 2009.

Kim Heuiju. "Movement for East-Asia Federation of Korean residents in Kyoto, Japan and Cho Eun Je." The Kyoung-Ju Sa Hak, vol. 27, 2008, pp. 67-92.

Kim, Oegon. "Im Hwa's 'History of New Literature' and Orientalism." Korean Literary Theory and Criticism, vol. 5, 1999.

Koiso Kuniaki. "Establishment of Moral Joseon." Chunchu, 1942.

Lee, Chulwoo. "Modernity, Rule by Law and Power under Occupation." Colonial Modernity in Korea. Translated by Do Myunhee. Edited by Gi-Wook Shin and Michael Robinson. Samin, 2006.

Lee, Jinhyoung. Theories of Novel of the Colonial Korea in the Late 1930's. Somyong, 2013.

Keßler, Peter. "Standort suche für eine historische-materialistische Theorie des

Romangenres." Disput über den Roman, edited by M. Wegner, B. Hiller, P. Keßler, and G. Schaumann, Aufbau Verlag, 1988.

Nakamura Mitsuo, and Nishitani Keiji. The Ideal of Pacific War. Translated by Lee

Kyounghoon, Song Taewook, Kim Yungshim, and Kim Kyungwon. Imagine, 2007.

Osborne, Peter, The Politics of Time. Verso, 1995.

Yonetani Masahumi. Asia/Japan. Translated by Jo Eunmi. Greenbee, 2010.

Young, Robert J. C. Colonial Desire. Routledge, 1995. 